\title{
MODERN APPROACHES TO THE ASSESSMENT OF THE HEALTH EFFECTS OF ODORS CAUSED BY AIR POLLUTANTS
}

\author{
Slautenko Ye., Morhulova V.
}

\section{СУЧАСНІ ППДХОДИ ДО ОЦПНКИ ВПЛИВУ НА ЗДОРОВ'Я НАСЕЛЕННЯ ЗАПАХІВ, ОБУМОВЛЕНИХ ЗАБРУДНЮЮЧИМИ РЕЧОВИНАМИ ПОВІТРЯ}

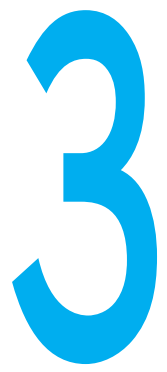

СЛАУТЕНКО Є.Г., МОРГУЛЬОВА В.В.

ДУ «Інститут громадського здоров'я НАМН України

ім. О.М. Марзєєва», м. Київ

УДК $614.718: 636.4: 351.777$

Ключові слова: запахи, атмосферне повітря, хімічні речовини, математичне моделювання. а визначенням ВОО3, «здоров'я $є$ станом повного фізичного, психічного та соціального благополуччя, а не тільки відсутністю хвороб та фізичних дефектів». У зв'язку з великою кількістю населення, яке проживає поблизу тваринницьких комплексів, і стрімким розвитком цих промислових об'єктів на території нашої країни постійно виникає питання щодо впливу запахів на населення.

Нюховий апарат людини здатен розрізняти майже 10000 відтінків запаху, проте, на відміну від більшості інших хребетних, людина починає відчувати їх лише тоді, коли концентрація запахової речовини стає досить високою. Сучасна концепція визначення поняття запаху полягає у тому, що запах - це рецепторне сприйняття хімічної речовини будьякої природи та будови, що відбувається на молекулярному рівні. Відчуття запаху, у свою чергу, являє собою своєрідний біоелектричний сигнал, який сам, незалежно від властивостей речовини, що є його основою, здатний викликати певні психофізіологічні реакції
3 боку організму людини. Чутливість людини до запаху залежить від виду речовини, що викликає запах. У людини дуже розвинена чутливість до запахів, що сигналізують про небезпеку виникнення отруєння (сірководень, метилмеркаптани, диметилсульфіди тощо), небезпеки пожежі (н-крезол, н-масляний-альдегід) або естетичне несприйняття запаху поту та немитого тіла (масляна та ізовалеріанова кислоти) [1]

Основною особливістю впливу запахів на організм людини $€$ те, що за відсутності прямого впливу він проявляється опосередковано - через рецептори нюхових клітин нюхової цибулини, які впливають на вегетативні центри та вищі функції кори головного мозку, викликаючи певні вегетативні або психоемоційні реакції організму [1, 2]. Вищенаведене зумовило необхідність удосконалення методів оцінки впливу хімічного забруднення атмосферного повітря у районах розташування тваринницьких комплексів і сельбищних зон поблизу цих об'єктів.
СОВРЕМЕННЫЕ ПОДХОДЫ К ОЦЕНКЕ ВЛИЯНИЯ ЗАПАХОВ, ОБУСЛОВЛЕННЫХ

ЗАГРЯЗНЯЮЩИМИ ВЕЩЕСТВАМИ ВОЗДУХА

Слаутенко Е.Г., Моргулева В.В.

ГУ «Институт общественного здоровья им. А.Н. Марзеева НАМН Украины», Г. Киев

Обсуждаются отдельные вопросы восприятия запаха и его влияния на здоровье человека, классификация запахов, гигиеническая роль, современные методы их исследования и оценки влияния на здоровье человека. Описан новый подход к изучению запахового загрязнения атмосферного воздуха.

Цель работы: анализ методов оценки химического загрязнения атмосферного воздуха запахообразующими веществами и распространения запахов на основе собственных исследований и литературных данных.

Материалы и методы: аналитический и библиосемантический методы, моделирование рассеивания загрязняющих веществ в атмосферном воздухе.

Результаты. Для использования на практике на основе принципа математического моделирова- ния предложена методика определения распространения химических веществ с выраженными запахообразующими свойствами, присутствующих в выбросах свинокомплексов и потенциально влияющих на здоровье населения, проживающего в зоне ближайшей жилой застройки Данная методика может быть использована для уточнения размеров СЗЗ современных свинокомплексов и оценки распространения в атмосферном воздухе указанных выше веществ. В расчеты вводился также показатель безопасности для здоровья человека в виде величины запахообразующего фактора согласно классификации пункта C 0,18-1. Полученные результаты, рассчитанные в геоинформационной системе, позволили уточнить размеры санитарнозащитных зон.

Выводы. Разработан новый подход к оценке распространения химических веществ С выраженными запаховыми свойствами, а также $к$ оценке влияния запахов на здоровье человека.

Ключевые слова: запахи, атмосферный воздух, химические вещества, математическое моделирование.

() Слаутенко Є.Г., Моргульова В.В. СТАТТЯ, 2018. 
Мета: аналіз методів оцінки хімічного забруднення атмосферного повітря запахоутворювальними речовинами та поширення запахів (на основі власних досліджень та літературних даних).

Методи дослідження. Аналітичний та бібліосемантичний методи - для проведення аналізу класифікацій та методів оцінки запахів на здоров'я людини. Для моделювання розсіювання забруднювачів використано програму математичного моделювання ISC AERMOD View, яка дозволяє оцінити концентрації забруднювачів за 1 годину, добу, місяць та рік, усереднені за часом, метеопараметрами, показниками інфраструктурного устрою для оцифрованих рельєфів території дослідження, де розташовані підприємства. Дане програмне забезпечення допомагає розрахувати забруднення атмосферного повітря хімічними речовинами на підставі використання гаусової моделі розрахунку шлейфу розсіювання шкідливих речовин від стаціонарних джерел. Це проводилося з урахуванням проведених натурних досліджень та формування короткострокових та довгострокових прогнозів розсіювання речовин від джерела

Результати досліджень. На початку нейрофізіологічних досліджень впливу запахів на організм людини було відзначено, що окремі запахи впливають на настрій та самопочуття людини, зокрема поява неприємних, відразливих запахів викликала у піддослідних-волонтерів нудоту, запаморочення, непритомність тощо [2].

Цей механізм було відкрито 2004 року Р. Екселом та

Л. Баком, відповідно до досліджень яких було встановлено, що нейрони, які входять до структури нюхового апарату людини, експресують близько 1000 рецепторних білків, кожен з яких взаємодіє за типом "ключзамок" з молекулами запахових речовин, які потрапляють до носових ходів при диханні. Рецепторні білки постійно перебувають на поверхні аксонів нюхового нейрону, і за взаємодії з молекулою запахової речовини генерується електрохімічний імпульс, що містить інформацію про природу запаху, та передається далі по нюхових волокнах. Після цього нюховим нервом імпульс поширюється і акцептується нейронами нюхової цибулини, звідки через синаптичні закінчення передається безпосередньо до вищих нюхових центрів, центрів емоцій та пам'яті головного мозку, де відбувається аналіз інформації про природу і характеристики запаху та її подальше запам'ятовування [2].

Сучасна класифікація запахів була розроблена Г. Звордемайкером (1895) та доповнена Р. Харпером (1968). За основу у класифікації Г. Звордемайкера взято тривалість відчуття запахів. Класифікація Р. Харпера враховує власне відчуття запахів за допомогою нюхового аналізатора та відчуття, що сприймалися піддослідними при подразненні запаховою речовиною специфічних чутливих волокон n. trigeminus [4].

3 урахуванням даних робіт було розроблено сучасну шкалу безпечності запахів, принцип якої полягає у тому, що запахопопереджувальна здатність хімічної речовини оцінюється показником безпечності запаху (ПБЗ), що відповідає співвідношенню безпечного

\section{Таблиця 1}

Класифікація безпечності запаху хімічних речовин (за запахопопереджувальною здатністю)

\begin{tabular}{|c|c|c|}
\hline $\begin{array}{c}\mathcal{E} \\
\underline{5}\end{array}$ & $\begin{array}{c}\text { Величина запахо- } \\
\text { попереджуваль- } \\
\text { ного фактора }\end{array}$ & Пояснення \\
\hline A & $>550$ & $\begin{array}{c}\text { Понад 90\% людей реагують на появу запаху } \\
\text { на рівні ГДК забруднювача у повітрі }\end{array}$ \\
\hline B & $26-550$ & $\begin{array}{c}50-90 \% \text { людей реагують на появу запаху } \\
\text { на рівні ГДК забруднювача у повітрі }\end{array}$ \\
\hline C & $1-26$ & $\begin{array}{c}\text { Менше 50\% людей реагують на появу запаху } \\
\text { на рівні ГДК забруднювача у повітрі }\end{array}$ \\
\hline D & $0,18-1$ & $\begin{array}{c}10-50 \% \text { уважних людей реагують на появу } \\
\text { запаху на рівні ГДК забруднювача у повітрі }\end{array}$ \\
\hline E & $<0,18$ & $\begin{array}{c}\text { Менше 10\% уважних людей реагують на появу } \\
\text { запаху на рівні ГДК забруднювача у повітрі }\end{array}$ \\
\hline
\end{tabular}

рівня цієї речовини у повітрі та граничної концентрації сприйняття запаху. Будь-яка хімічна речовина, для якої ПБЗ становитиме менше одиниці, розглядається як потенційно небезпечна з тих позицій, що ії небезпечні для здоров'я людини концентрації не можуть бути визначені шляхом відчуття запаху (табл. 1).

Відповідно до класифікації вважається, що речовини класу $A \in$ найбільш безпечними, тобто такими, що сприймаються переважною більшістю населення, тоді як речовини класу Е становлять найбільшу небезпеку через те, що незважаючи на присутність їх у повітрі на межі безпечного рівня і вище вони викликають відчуття запаху лише у 10\% уважних (попереджених) спостерігачів [5]

Важливою особливістю сприйняття запахів також $є$ те, що за постійного впливу сильної за своїми запаховими властивостями речовини у більшості людей формується т.з. нюхова адаптація. Потенційна небезпека цього явища полягає у тому, що хоча великі промислові підприємства, автомагістралі, сміттєспалювальні заводи тощо і викидають в атмосферне повітря речовини класу $\mathrm{A}$ та $\mathrm{B}$, за деякий час нюхові рецептори людей, що проживають біля зазначених вище об'єктів, адаптуються i, відповідно, перестають реагувати на них. У подальшому, навіть 3 суттєвим збільшенням концентрації забруднювачів в атмосферному повітрі населеного пункту, людина не відчуває цього. Не менш небезпечною є властивість нюхових рецепторів людини переставати розрізняти специфічний запах забруднювача за різких збільшень його концентрації [5].

Так, наприклад сірководень при збільшенні його концентрації у повітрі у 1000 разів зовсім не відчувається через блокування рецепторів нюхових клітин, і його потенційно летальні концентрації не можуть бути визначені за запахом без інструментальних методів дослідження.

Дуже важливою властивістю $€$ зворотна залежність інтенсивності запаху від концентрації самої запахової речовини. Прикладом даного феномену є меркаптани - летючі похідні 
MODERN APPROACHES TO THE ASSESSMENT OF THE HEALTH EFFECT OF ODORS CAUSED BY AIR POLLUTANTS

Slautenko Ye., Morhulova V.

State Institution "O.M. Marzeiev Institute for Public Health, NAMS of Ukraine, Kyiv

State of the problem. Some questions of odor perception and its influence on human health, odor classification and hygienic role, modern methods of their study and evaluation of the effect on human health are discussed. A new approach to the study of odor pollution of ambient air is described.

Objective. Analysis of methods for assessing the chemical pollution of ambient air with odor-forming constituents and the spread of odors based on our own research and literature data.

Materials and methods: analytical, bibliosemantic methods, modeling of pollutants dispersion in the ambient air.

Results. Based on the principle of mathematical modeling we proposed for use in practice the method of determining the distribution of the chemical substances with pronounced odor-forming properties, which are present in the emissions of pig-breeding complexes and potentially affecting the health of the population, living in the zone of the nearest residential development. This method can be used to specify the size of the SPZ of modern pig-breeding complexes and evaluation of the distribution of the above substances in the ambient air. In the calculations, a safety index for human health was also introduced in the form of an odor-forming factor, equal to the classification of point $C 0.18-1$. The results, calculated in the geoinformation system allowed to specify the size of sanitary protection zones.

Conclusions. A new approach to the assessment of the spread of chemicals with pronounced odor properties has been developed, as well as an assessment of the effect of odors on human health.

Keywords: odors, ambient air, chemical substances, mathematical modeling. вуглеводнів, в яких атом водню заміщений сульфгідрильною групою $-\mathrm{SH}$, які виявляються у повітрі підприємств при виробництві целюлози, переробці сірчистої нафти тощо, утворюються під час розкладання білкових речовин і мають різкий гнилісний запах, добре відчутний навіть у мізерно малих концентраціях меркаптанів у повіт-

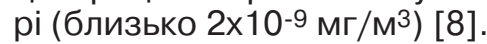

Гігієнічне значення запахів полягає у тому, що у зв'язку 3 суттєвою зміною картини забруднювачів атмосферного повітря особливої уваги заслуговує забруднення атмосферного повітря хімічними речовинами 3 вираженими неприємними запаховими властивостями. Здебільшого дана проблема стосується населених пунктів, розташованих у сільській місцевості. Причиною цього стало значне збільшення промислових підприємств аграрної та харчопереробної галузі, особливо ця тенденція характерна для підприємств 3 розведення та вирощування свиней [8].

Зазначена проблема посилюється тенденцією будівництва нових потужних промислових об'єктів на територіях колишніх колгоспних тваринницьких ферм, об'єктів 3 обслуговування сільськогосподарської техніки, сільськогосподарських підприємств різного профілю та інших об'єктів, що мають наявні інженерні комунікації та розташовані у межах населених пунктів сільської місцевості. Особливістю такого будівницт- ва $є$ те, що фактичні розміри санітарно-захисних зон (СЗ3) сучасних потужних підприємств агропромислового комплексу (АПК) часто не відповідають нормативним показникам і, як наслідок, житлова забудова населених пунктів поблизу підприємств АПК перебуває у межах С33 що, відповідно, збільшує потенційний ризик для здоров'я населення.

Серед хімічних сполук, що присутні у викидах від свинарських підприємств, принаймні 700 сполук мають такі характеристики запаху, як «неприємний», «різкий» або «нестерпний» [9].

Основними хімічними речовинами, що складають найбільшу частину запахового навантаження, є органічні продукти білкової деградації, здебільшого азотної та сіркової природи - аміак, диметиламін, сірководень, метилмеркаптан, диметилсульфід тощо. У дослідах на добровольцях було виявлено, що запахи таких речовин впливають на зміну потенціалів електричної активності структур головного мозку, частоти серцевих скорочень, електродермальної активності тощо. Шляхом спостережень було встановлено, що вплив запахів подібної природи має здатність викликати у певних груп людей (вагітні, літні люди, особи 3 психічними порушеннями, онкологічні хворі) різкі зміни настрою, вегетативні порушення, клінічні ознаки розладів поведінки. Подібні результати являють значний інтерес для дослідження, оскільки прямо вказують на те, що запахи є такими ж небезпечними факторами забруднення, як і фізичні, хімічні або біологічні чинники.

2003 року у Великобританії було введено стандарти для вимірювання неприємних запахів, для оцінки вираженості яких було введено систему балів (одиниць). Так, за прийнятими правилами, допустима концентрація неприємного запаху у житлових районах міст має складати не більше п'яти одиниць, у сільській місцевості - вісім, а безпосередньо на виробничих майданчиках десять. Такий поріг дозволяється перевищувати не більше ніж 7 днів на рік.

Протягом 2001-2009 років рядом науковців США, ЄС та Японії було запропоновано введення поняття порогу запаxy (odor threshold) як межі, вище якої відзначається його вплив на людський організм. За результатами низки досліджень було встановлено орієнтовні пороги запахів для понад 1000 хімічних речовин [10].

Сучасні методи дослідження запахів та їхніх властивостей суттєво відрізняються від тих, з яких починалося дослідження нюхової функції людини. Це пов'язано з різким зменшенням піддослідних-волонтерів та 3 принциповою зміною акцентів дослідження, що пов'язано 3 бажанням відійти від переважно суб'єктивних методів оцінки рівня запаху (зокрема, ольфактометрія). 
бачення можна розбити на квазистійкі періоди за метеорологічними умовами. Для довгострокових прогнозів застосовується попередньо обрахована річна концентрація забруднюючої речовини, річна роза вітрів, характерна для даної місцевості. Окремі показники розбиваються на класи, такі як швидкість вітру, напрямок вітру, параметри атмосферної стійкості, висота інверсії, температура, вологість.

На основі принципу матема-

"Золотим стандартом" для дослідження запахів різної природи у повітрі нині $€$ так званий "електронний ніс". 3 кінця 90-х років минулого сторіччя розпочалися активний пошук і розробка приладу, який би імітував нейрофізіологічну модель сприйняття запахів 3 наступним їх аналізом. Термін "електронний ніс" вперше з'явився у 1987 році. Нині цей термін використовується для визначення низки приладів, що містять масив електронних хімічних сенсорів часткової специфічності та систему структур для розпізнавання простих та складних запахів [5]. "Електронний ніс" реагує на присутність газу або газової суміші зміною фізичних характеристик своїх сенсорів (електричних, оптичних тощо) [4-6].

Останніми роками найбільш поширеним методом виявлення рівня запаху став метод математичного моделювання, заснований на моделях адитивності (ADD-модель), Евклідової адитивності (ЕА-модель), моделі переважаючого компонента (SC-модель), Гаусової моделі, векторної моделі тощо. Популярність даного методу пов'язана з відсутністю необхідності залучення навчених одораторів або волонтерів, що суттєво зменшує ризик недостовірності оброблених даних [11].

Нами проводилося моделювання розсіювання за допомогою програмного забезпечення ISC AERMOD View [12]. Короткострокові прогнози здійснювалися за допомогою моделей, що розраховують карту забрудненості району для одного часового періоду, якому відповідають порівняно стійкі метеорологічні умови. Ці ж моделі можуть бути використані і для довгострокових прогнозів, якщо інтервали перед- тичного моделювання запропоновано для використання у практиці методику визначення поширення хімічних речовин 3 вираженими запахоутворювальними властивостями, що присутні у викидах від свинокомплексів та потенційно впливають на здоров'я населення, яке проживає у зоні житлової забудови поблизу [6]. Дана методика може бути використана для уточнення розмірів СЗ3 сучасних свинокомплексів та оцінки поширення в атмовище речовин. До розрахунків вводилися також показники безпечності для здоров'я людини, наведені у таблиці 1, у вигляді величини запахоутворювального фактора згідно 3 класифікацією пункту С 0,18-1. Отримані результати, обраховані у геоінформаційній системі, дозволили уточнити розміри санітарно-захисних зон.

\section{Висновок}

Проведені дослідження дозволили обґрунтувати існування можливості проведення оцінки впливу запахоутворювальних речовин на підставі математичного моделювання. Даний метод дозволить більш змістовно проводити санітарноепідеміологічну експертизу з урахуванням впливу сучасних потужних тваринницьких об'єктів на забруднення атмосферного повітря та розробляти профілактичні заходи для населення, що проживає поблизу цих об'єКтіВ.

\section{ЛІТЕРАТУРА}

1. Майоров В.А. Запахи: их восприятие, воздействие, устранение. М. : Мир, 2006. C. 45-48.

2. Axel R. The molecular logic of smell. Scientific American. 1995. Vol. 273. № 4.

P. 151-158.

3. Amoore J.E. Odor theory and odor classification. сферному повітрі зазначених
Fragrance chemistry. The science of the sense of smelt / E.T. Theimer (ed.). N.Y., London : Academic Press, 1982.

P. 27-35.

4. Mahin T.D. Comparison of Different Approaches Used to Regulate Odors Around the World. Water Science and Technology. 2001. Vol 44, № 9. P. 87-102.

5. Menini A., Picco C., Firestein S. Quantal-like current fluctuations induced by odorants in olfactory receptors cells.

Nature. 1995. Vol. 373. № 6513. P. 235-241.

6. Турос О.І., Слаутенко Є.Г., Моргульова В.В., Петросян А.А., Ананьєва О.В. Визначення розповсюдження запахів, що утворюються у процесі діяльності свинокомплексів. Київ, 2017. 9 с. (Інформ. лист № 300/ ДУ «нститут громадського здоров'я ім. О.М. Марзєєва НАМН України»).

7. Rock F., Barsan N.,

Weimar U. Electronic Nose:

Current Status and Future

Trends. Chemical Reviews. 2008. Vol. 108, № 2. P. 705-725.

8. Ciganek M., Neca J.

Chemical characterization of volatile organic compounds on animal farms. Veterinary medicine. 2008. Vol. 53. № 12.

P. 641-651.

9. Zahn J.A., DiSpirito A.A. Correlation of human olfactory responses to airborne concentrations malodorous volatile organic compaunds emitted from swine effluent. Journal of Environmental Quality. 2001. Vol. 30. № 2. P. 624-634.

10. Van Harreveld A.Ph. Odor Regulation and the History of Odor Measurement in Europe. Barcelona, 2005. P. 54-61.

11. Bunton B., O'Shaughnessy P., Fitzsimmons S.,

Gering J., Hoff S., Lyngbye M. et al. Monitoring and Modeling of Emissions from Concentrated Animal Feeding Operations: Overview of Methods. Environ. Health Persp. 2007. № 115 (2) : P. 30-307.

12. Пат. 33659 Україна, МПК (2006) G01N31/00. Спосіб визначення осереднених концентрацій шкідливих речовин в атмосферному повітрі / Турос O.І., Петросян А.А., Картавцев О.М., Вознюк О.В., Михіна Л.І., Мельник Є.А; заявник і патентовласник ДУ «Інститут гігієни та медичної 
екології ім. О.М. Марзєєва Академії медичних наук України». - и 2008 00699; заявл. 21.01.2008; опубл. 10.07.2008.

Бюл. № 13.

\section{REFERENCES}

1. Maiorov V.A. Zapakhi: ikh vospriiatie, vozdeistvie, ustranenie [Odor: its Perception, Impact, Elimination]. Moscow : Mir ; 2006 : 45-48 (in Russian).

2. Axel R. Scientific American 1995 ; 273 (4) : 151-158.

3. Amoore J.E. Odor Theory and Odor Classification. In : Theimer E.T. (Ed.). Fragrance Chemistry. The Science of the Sense of Smelt. N.Y., London : Academic Press ; 1982 : 27-35.

4. Mahin T.D. Water Science and Technology. 2001; 44 (9) : 87-102.

5. Menini A., Picco C. and Firestein S. Nature. 1995 ; 373 (6513) : 235-241.

6. Turos O.I., Slautenko Ye.G., Morgulova V.V., Petrosian A.A. and Ananieva O.V. Vyznachennia rozpovsiudzhennia zapakhiv, shcho utvoriuiutsia $v$ protsesi diialnosti svynokompleksiv : informatsiinyi lyst [Determination of the Distribution of Odors Formed during the Operation of Pig Farms : Information Letter]. Kyiv; 2017 : 9 p. (in Ukrainian).

7. Rock F., Barsan N. and Weimar U. Chemical Reviews. 2008 ; 108 (2; 19 January) : 705-725.

8. Ciganek M. and Neca J. Veterinary medicine. 2008 ; 53 (12) : 641-651.

9. Zahn J.A. and DiSpirito A.A. Journal of Environmental Quality. 2001 ; 30 (2) : 624-634

10. Van Harreveld A.Ph. Odor Regulation and the History of Odor Measurement in Europe. Barcelona ; 2005 : 54-61.

11. Bunton B., O'Shaughnessy P., Fitzsimmons S., Gering J., Hoff S., Lyngbye M. et al. Environ. Health Persp. 2007 ; 115 (2) : 303-307.

12. Turos O.I., Petrosian A.A., Kartavtsev O.M., Vozniuk O.V., Mykhina L.I. and Melnyk Ye.A; Pat. 33659 Ukraine, MPK (2006) G01N31/00. Sposib vyznachennia oserednenykh kontsentratsii shkidlyvykh rechovyn $v$ atmosfernomu povitri [A Method for Determining the Average Concentrations of Harmful Substances in the Atmosphere]. 21.01.2008; publ. 10.07.2008; Biul. № 13 .

Надійшла до редакції 24.01.2017

\section{PRINCIPLES OF PREVENTION OF THE HARMFUL INFLUENCE OF INDUSTRIAL ATMOSPHERIC POLLUTION ON THE STATUS OF POPULATION HEALTH Grebnyak N.P., Fedorchenko R.A. ПРИНДИПИ ПРОФІЛАКТИКИ ШКІДЛИВОГО ВПЛИВУ
ІНДУСТРАЛЬНИХ АТМОСФЕРНИХ ЗАБРУДНЕНЬ
НА СТАН ЗДОРОВ'И НАСЕЛЕННЯ}

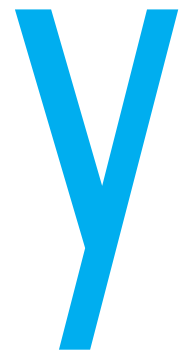

ГРЕБНЯК М.П., ФЕДОРЧЕНКО Р.А.

Запорізький державний медичний університет, м. Запоріжжя, Україна

УДК 614.71:502.3:504.5] - 084

Ключові слова: забруднення повітря, профілактика шкідливого впливу. сучасних умовах однією 3 найактуальніших медико-соціальних проблем $є$ оцінка зменшення ризиків для здоров'я населення. За даними ВООЗ, забруднення повітря є одним 3 основних факторів ризику для здоров'я, пов'язаних з навколишнім середовищем: близько 80\% захворювань тією чи іншою мірою залежать від його якості [1]. Науково-технічний прогрес формує нове довкілля [2-4]. Внаслідок техногенного навантаження відбуваються глобальні зміни навколишнього середовища, які зумовлюють значне забруднення, руйнування природи, зниження адаптаційних резервів організму людини до дії різних факторів [5, 6]. Пріоритетним напрямком усіх профілактичних і природоохоронних заходів $€$ здоров'я

ПРИНЦИПЫ ПРОФИЛАКТИКИ ВРЕДНОГО ВЛИЯНИЯ ИНДУСТРИАЛЬНЫХ АТМОСФЕРНЫХ ЗАГРЯЗНЕНИЙ НА СОСТОЯНИЕ ЗДОРОВЬЯ НАСЕЛЕНИЯ

Гребняк Н.П., Федорченко Р.А.

Запорожский государственный медицинский університет, г. Запорожье, Украина

Целью исследования было обоснование принципов профилактики неблагоприятного воздействия индустриальных атмосферных загрязнений на здоровье населения.

Материалы и методы. Для оценки экспозиции атмосферных загрязнений для здоровья населения индустриального города изучены валовые выбросы от стационарных и передвижных источников по уровню и спектру поллютантов, корреляционная связь между суммарным загрязнением воздуха и болезнями органов дыхания, заболеваемость населения, коэффициенты детерминации.

Результаты. Методологические основы обоснования принципов и мероприятий профилактики развития болезней органов дыхания базируются на медико-экологическом мониторировании, установлении причинно-следственной связи между факторами внешней среды и состоянием здоровья, гигиенической оценке санэпидблагополучия. Обосновано 7 принципов первичной профилактики, объектом которой являются источник и механизм возникновения/распространения заболевания; 7 принципов вторичной профилактики, объектом которой является болезнь в острой или подострой стадиях; 3 принципа третичной профилактики, объект которой - инвалидность/преждевременная смертность.

Ключевые слова: загрязнение атмосферного воздуха, профилактика неблагоприятного воздействия на здоровье.

(ㄷ Гребняк М.П., Федорченко Р.А. СТАТТЯ, 2018. 